\title{
9 (The Economics of) Cultural Festivals in the Digital Age
}

\author{
An Analysis of the Comics \\ Publishing Industry
}

\author{
Elisa Salvador, Elena Castro-Martínez and \\ Pierre-Jean Benghozi
}

\section{Introduction}

Festivals are one of the most diffused examples of living production in the cultural and creative industries (CCIs) (Frey, 1994; Caves, 2000; Luonila, Johansson, 2016). However, up to the 1990s "the study of temporary events such as Festivals, markets, fairs and other ephemeral events" was relatively limited ${ }^{1}$ (Benghozi, Nénert, 1995: 66). In recent years, festivals have attracted increased attention and increased in number (del Barrio et al., 2012; Baez-Montenegro, Devesa-Fernandez, 2017). Moeran and Strandgaard Pedersen (2011) highlight that fairs, festivals, and competitive events are field-configuring events and enable ritualized industry practices. Several studies investigate various aspects related to the organization, management, and success of these events (cf. among others, del Barrio et al., 2012; Snowball, 2013; Vestrum, 2014; Wong et al., 2015; Dantas, Colbert, 2016; Baez-Montenegro, Devesa-Fernandez, 2017).

Since the earliest cultural economic and management studies, there have been several works that have focused on music and film festivals (cf. Section 1) which are the longest established festivals. They represent popular activities and are well-suited to public performances, events and shows to which these temporary events can be linked. However, few works look at festivals related to less popular sectors such as publishing. The aim of this contribution is to investigate these smaller events by conducting a case study of comics festivals to identify the nature of the dynamics and strategies at work. We consider their location, how the offers are structured and their strategic positioning in the publishing industry by examining the impact of two selected festivals organized in two small cities in France and Spain: the comics festivals in Angers ${ }^{2}$ (France) and Avilés ${ }^{3}$ (Spain). Detailed analysis of the characteristics of these selected festivals along their various editions, shows in which extent they clear up the structuration of a multi-faced economic model, and how they are linked specifically to the characteristics of the CCI sector. 
On the one hand, festivals constitute specific forms of territorial economic energization. Whatever their size, they contribute to the attractiveness and identity of the place hosting them through the local anchoring of cultural activities. On the other hand, the organization of festivals around a variety of activities - in our case about comics - highlights the possibility of conceiving innovative formats linked to local cultural or craft traditions.

From a methodological point of view, we rely on an analysis of public documentation on the festivals (i.e. promotional material, festival programs, media, and press articles available on the Internet) which allows identification of their main characteristics. We systematically explored this content. We also conducted face-to-face interviews between July 2016 and April 2019 with the festival organizers to complement the framework by identifying perceptions, comments, and precise development strategies fulfilled in the event organization.

The chapter is structured as follows: Section 1 provides an overview of festivals as events presented in the management literature; Section 2 offers a brief description of the selected festivals in France and Spain and Section 3 provides a discussion and some concluding remarks.

\section{The literature on festivals: a brief overview}

There are several reasons for the economic revival and local/regional interest in festivals. First, they support tourism developments and contribute to the economic revival of towns and territories. Since the 1960s, hundreds of festivals take place in Provence (France) during the summer and there is a large stream of research in cultural economics which focuses on the impact of these events (see below). They are seen as providing opportunities for small cities to establish an identity and acquire a visibility that otherwise might be difficult. The recent explosion in festivals could be related also to their experiential nature which distinguishes them from the increasing digital diffusion of culture. According to Luonila and Johansson (2016: 53), Festivals "promote celebration and a sense of community and produce experiences for a wide range of audiences". The presence of multiple festivals around the world with different cultural and creative focuses is well known. In 1994, Frey highlighted the rapid growth in the number of classical music and opera festivals. Frey $(1986,1994)$ was one of the first authors to investigate the festival phenomenon in depth. He focused on music festivals analyzing the economics and main characteristics of the Salzburg Festival. Also, several studies of cultural practices highlight a revival of amateur participation, a vibrant but often ignored aspect (Rajaobelina et al., 2019).

The motivations for cultural event and festival attendance have been the subject of several studies. For instance, Wong et al. (2015) focus on food festivals and highlighted the effects of quality, emotion, image, and satisfaction on loyalty to the event. Similarly, Baez-Montenegro and Devesa-Fernandez (2017) identify the factors that attract new festival visitors 
while retaining previous audiences. They focus on the case of a film festival and highlight the role of and relations among motivation, satisfaction, and loyalty.

Most research focuses on music, television, and film festivals. For example, Vestrum (2014) looks at music festivals and the embeddedness of community ventures within the local community. Luonila and Johansson (2016) examine the reasons for networking through the case study of an opera house and a music festival. Dantas and Colbert (2016) investigate the differentiating factors and longevity of the Festival de Lanaudière (Quebec), Canada's largest classical music festival. Vecco and Srakar (2017) estimated the effects of two Slovenian jazz music festivals on tourism inflows and the economic resilience of the host cities. Benghozi and Nénert (1995) analyze the Cannes film festival through a commercial and artistic logic: they were the first scholars to conduct a systematic analysis of the economics and the management of this international film event.

Food festivals also are important in rural and marginal areas and contribute to development, branding and local identity building. Local food is used to create a kind of "place branding" to enable the survival of rural localities (Blichfeldt and Halkier, 2014). Del Barrio et al.'s (2012) case study evaluates Spanish cultural festivals as examples of intangible cultural heritage. There are also several book festivals. Publishing is the oldest media and content industry subsector. The specific field of comic books (bandes dessinées, $B D s$, in French) attracts significant interest (Benghozi, Salvador, $2015,2016)$ and has great potential in the overall book publishing industry (Salvador, Benghozi, 2021). Comic books are a sector that is recognized worldwide but systematic investigations of its business practices are scarce (Mayfield et al., 2001).

The contribution of festivals to local or regional development in terms of attracting tourists, their marketing impact and image building has been investigated by several scholars ${ }^{4}$ (Frey, 1986, 1994) but few studies focus on the organization, structuring, and management of festivals and their nature and dynamics (Benghozi and Nénert, 1995).

The main characteristics of festivals include what Abfalter et al. (2012: 4) identify as "temporality, virtuality and a project focus". In general, "Festival organizations benefit from a highly committed and intrinsically motivated workforce, but they face the challenge of intensive short-term collaboration and the dominance of one or a few individuals" (Abfalter et al., 2012: 5). Events such as festivals tend to be the subject of intense seasonal organization involving both permanent staff and short-term employees recruited for a cyclical event taking place in a fixed time period generally the summer, and in a particular location (Abfalter et al., 2012: 6). Regular face-to-face meetings are complemented by e-mail exchanges to communicate among and share knowledge among event organizers (Abfalter et al., 2012). Reputation, image, brand (cf. the Cannes film festival in France, Benghozi, Nénert, 1995, or the Porispere music festival in Finland, 
Suomi et al., 2020), seasonality and level of institutionalization (Luonila, Johansson, 2016) are key to the perception of the festival.

The institution of festivals in the context of CCIs such as the publishing industry is somewhat paradoxical. The attractiveness and raison d'être of festivals are underpinned by their eventful, spectacular, and unique character. This raises questions about why festivals should survive around productions that are easily available from bookshops or libraries.

The case of the music industry shows that their survival is based on the development of new economic models precisely based on the articulation between dematerialization on the one hand, strengthening of living events like Festivals and concerts on the other hand. Therefore, it is important to understand the dynamics of industries such as book publishing, and requires a better understanding of festival success factors, economic models, type of offer, services, and experience they provide and their links with various types of local actors. From a research perspective, it would seem interesting to analyze more specifically festivals where neither their size nor exclusivity is sufficient to explain the programming and the notoriety. This focus allows more precise identification of the structuring dynamics at work beyond the most obvious event spectacle dimensions.

The context is shaped strongly by the geographical and territorial anchoring of development models and the development of information and communication technologies (ICTs) has likely had an impact on festivals. They enable dematerialization of production and availability and consumption of cultural content and have had a disruptive effect on CCIs, value chains, sector organization, traditional business models, and role and importance of the various economic players. The digital revolution has had a disruptive effect on the traditional CCI model with the book publishing and the music and cinema industries the most affected (Benghozi et al., 2018; Salvador et al., 2019). The music sector was the first to experience disruption in the 1990s and shows that these technologies stimulate unprecedented hybridization dynamics based on the coupling of global and dematerialized online (e.g. offshore) markets with stronger local and physically anchored activities such as concerts. These hybridizations can be found also in other cultural industries including those always considered digital such as videogames. The videogame sectors in recent years has extended to include e-sports and performing arts alongside massive multiplayer gaming.

Whether and to what extent these digital technologies have also influenced the nature and ecosystem of festivals, and whether festivals have exploited these new resources to develop new business models and consolidate and expand their format, notoriety, and audiences are issues that need investigation. With the exception of the unprecedented period of the covid-19 pandemic which forced festivals to reinvent themselves to compensate for the containment and banning of public events, first observations of festivals show relatively limited appropriation of digital technologies. The technologies adopted seem to be focused mainly on improving preparation and 
support functions (remote relations, administration, ticketing) and communication (promotion, program information). Smaller festivals seem not to have been affected by digital innovations due, perhaps, to the local links and the unique experiences they promise which are not easily substituted by digital experiences. These festivals achieve customer loyalty and increased attendance via word-of-mouth (Rajaobelina et al., 2019). However, digital strategies have a place: they support various services for festivals which are often under-staffed and depend on large numbers of volunteers, and increase visibility, and thus festival success through use of social networks such as Facebook and Twitter.

However, during the period of the covid-19 pandemic, which severely affected all cultural events, both small and large festivals and cultural institutions have had to innovate. Many were obliged to cancel events, but some tried to provide the festival experience using digital means. ${ }^{5}$

\section{The case of the two festivals in France and Spain}

In this section, we provide a description of the characteristics of the cases including their focus and objectives and their organization and management. Table 9.1 summarizes some key elements of the selected festivals.

\section{The comics festival in Angers, France}

\section{Main focus and objectives}

The Angers comics festival is run by a non-profit organization (see Table 9.2) and has been held annually since 1999 during the first weekend of

Table 9.1 A snapshot of the two festivals

\begin{tabular}{|c|c|c|c|c|c|c|c|}
\hline Festival & $\begin{array}{l}\text { Year of } \\
\text { creation }\end{array}$ & Period & $\begin{array}{l}\text { Number } \\
\text { of days }\end{array}$ & $\begin{array}{l}\text { Number } \\
\text { of visitors } \\
\text { (latest } \\
\text { editions) }\end{array}$ & $\begin{array}{l}\text { Ticket } \\
\text { price }\end{array}$ & $\begin{array}{l}\text { Budget } \\
\text { (on } \\
\text { average) }\end{array}$ & $\begin{array}{l}\text { Communication } \\
\text { channels }\end{array}$ \\
\hline $\begin{array}{l}\text { Comics } \\
\text { Festival } \\
\text { in } \\
\text { Angers, } \\
\text { France }\end{array}$ & 1999 & December & 2 & $>3,000$ & $\begin{array}{c}5 \text { euros } 1 \\
\text { day, } 6 \\
\text { euros } \\
2 \text { days }\end{array}$ & $\begin{array}{r}60,000 \\
\text { euros }\end{array}$ & $\begin{array}{l}\text { Radio, local } \\
\text { press, comics' } \\
\text { specialized } \\
\text { websites, } \\
\text { Facebook }\end{array}$ \\
\hline $\begin{array}{l}\text { Comics } \\
\text { Festival } \\
\text { in Avilés, } \\
\text { Spain }\end{array}$ & 1996 & September & 5 & $\begin{array}{r}30,000- \\
35,000\end{array}$ & 0 euros & $\begin{array}{l}27,500 \\
\quad \text { euros }\end{array}$ & $\begin{array}{l}\text { Radio, local } \\
\text { press, comics' } \\
\text { specialized } \\
\text { websites, } \\
\text { Facebook, } \\
\text { Twitter }\end{array}$ \\
\hline
\end{tabular}

Source: Authors, based on websites and interviews. 
December. It was aimed initially at promoting the comic culture in the local Maine-et-Loire area but received visibility at the national level as one of the first festivals dedicated to comics. This particular publishing sector has experienced phenomenal growth and success in recent years particularly among younger audiences. One of the novelties of this festival is that it provides an evidential and exclusive dimension which is not provided by comic book publications. The organizers focused on building a link between a traditional aspect of the culture of Angers - wine growing - and comic book authors. The first edition of the festival - "Vini BD 1re Cuvée"6 - was held at the beginning of December 1999 in the Angers Congress Centre. Since then the festival has been advertised as the "Angers BD" (Angers Comics) but wine growers have always been present although in small numbers.

The location was chosen because Angers is a big town with good infrastructure and good tourist facilities, and the capabilities to organize a national event. It also has the most comics' shops in France and is home to comics artists. The aim was to promote local comics authors and the city of Angers. The municipality of Angers, the Pays de la Loire region and local sponsors (i.e. companies and mass media) support this annual event which has an overall budget of around $€ 60,000$. The number of visitors has increased from around 1,500 in 1999 to more than 3,000 for the most recent festivals, with ticket prices of around $€ 5-6$.

The comics festival is one of the most prominent events in Angers cultural programming. It has grown rapidly and is the most important comic event in the Pays de la Loire region in terms of number of visitors, is ranked first in the Pays de la Loire region for number of paid entries and is well known in the comic world.

The originality of this event is to link the universal passion for comics to the local viticulture tradition of Anjou. As mentioned above, its novelty is based on the link between comic authors and local wine producers. ${ }^{7}$ The meeting between Angers' wine growers and comics' designers give birth to wine stickers during every edition of the Festival since its very first one. The festival founders wanted to create something different and an event that was anchored in the local culture of Angers. Therefore, the association between wine and comics is one of the main differentiation factors of the Angers Festival in the overall market of comics' Festivals. "Wine and comics are synonymous with good taste and joy of life: it makes sense that they unite" ${ }^{9}$ (Le Courrier de l'ouest, 1999). It also increases the visibility of the festival beyond the city's borders based on sales of bottles of wine with customized labels.

The festival offers opportunities for dedication sessions that are used to be crowded with a long queue of "passionate comics' hunters" to obtain signed copies of certain comics, dedicated to themselves and seen as an artwork. Since the first edition of the festival, these dedication opportunities and auctions of comics have taken place during the two days of the 
festival. This festival also hosts several bookshops which specialize in new and used comics, as well as collection books, exhibitions, and sponsors village. Dedications are a phenomenon of the comics sector and consist of a personalized drawing usually on the first page of the book. These can be more or less accurate representations and be more or less original but are valued by their buyers. Some visitors collect dedications from certain authors and visit the festival every year to collect additional dedications. However, the festival organizers' main aim is for visitors to discover the comics world.

Over the years, the comics festival has included additional attractions. For example, the third edition in 2001 included a comics' competition for young people aged between 14 and 24 years. The competition consisted of submitting a comic cartoon that carried a road safety message. This proved so successful that the competition has been repeated in all succeeding festivals including displays of the previous year's cartoons. Another characteristic of the Angers comics festival is the involvement of volunteer college students. The tenth edition (2010) of the festival for the first time included manga which are Japanese comics or graphic novels.

These annual festivals are organized around a specific topic ${ }^{10}$ that is investigated by an artistic, playful, didactic, and pedagogical approach. The festival provides entertainment for comics buffs and people interested to experience and discover the world of comics through attending exhibitions, conferences, and animations. Each edition of the festival is in partnership with another local actor such as Angers castle, ${ }^{11}$ the Angers mediatheque, or local libraries which host exhibitions before, during, and after the festival. Other partners in addition to the local wine growers include institutions such as the town council, companies (Librairie Richer, Anjou Cola, Game cash, Hotel Mercure, Angers congress center), media (Ouest-France, radio NRJ). The festivals include quizzes and games with comics as prizes. The 18th edition (2016) for the first time partnered with a sports club, and 5,000 flyers advertising the festival were distributed at a football match between Angers and Nantes on the day before the festival opened. Match attendees were offered a $€ 1$ reduction on the entry ticket price. It is advertised also on the radio and in the local press, and on comics' websites.

\section{Organization and management}

Festivals are temporary and cyclical events, and their organization evolves throughout the year. The preparation phase relies on a core group of permanent staff (around 20 persons) who are all volunteers. In the peak festival period, additional volunteers are recruited to manage the event and the partnerships and public relations. Between these two periods, the organization gradually increases and then declines after the end of the festival. The festival organization involves around 30-40 volunteers. 
The festival founders were seven comic shop customers living in Angers of various ages and socio-professional origins. They meet once a month throughout the year and exchange e-mails and telephone calls between meetings. The Angers festival is a non-profit organization characterized by a small number of permanent staff who plan these annual events on a voluntary basis. As the time of the festival approaches, the meetings become more frequent. Abfalter et al. (2012:13) argue in the case of the Colorado music Festival that "information technology infrastructure would enhance the sharing of knowledge outside the season, when the staff are dispersed" but this is not required for the Angers comics' festival.

The interviews with some of the festival organizers showed that the main motivation for joining the organization was to "create the event that he wanted to see when he was a child". The fact of "creating something and meet at a regular basis other persons sharing the same interests" is a strong motivation for the organizers. A surprising finding was that not all the organizers are passionate or comics readers: some contribute specific competences such as accounting. All share an interest in organizing a friendly, safe, and welcoming event (Abfalter et al., 2012). One interviewee emphasized the "conviviality" of the event and referred to seeing the same visitors every year and sharing a sort of "buman warmth". This conviviality has had a snowball effect on attracting more visitors. Also, "the other strong point is the way the organizers "cocoon" the authors. No red carpet, but a relaxed atmosphere where everyone takes pleasure to exchange on the projects of one and the other". ${ }^{12}$ Table 9.2 summarizes the relevant characteristics of the Angers festival.

Table 9.2 The Comics festival in Angers

Focus Promoting the comics' culture of Maine-et-Loire and around Maine-et-Loire. The aim was to promote local comics' authors and the city of Angers

Organization A non-profit organization called “Angers-BD”. 20-40 people of different ages and socio-professional origins. The organization is standardized but at a level of conviviality: the organizers are all volunteers

Activities Each festival focuses on a specific topic that is investigated by an artistic, playful, didactic, and pedagogical approach

Dedication sessions

Partnerships with local actors for exhibitions

Originalities Link between a traditional aspect of the culture of Angers - wine growers - and comics' authors: original wine stickers
Location advantage
Angers has the most comics' shops in France and several comics' designers live in Angers

Source: Authors. 


\section{Avilés international comics journeys, Spain}

\section{Main focus and objectives}

The Jornadas Internacionales del Cómic Villa de Avilés (Avilés International Comics Journeys) has been held in mid-September each year since 1996. The festival events take place in various locations in this small Spanish city which is located on the Northern coast of Asturias.

Avilés is medium sized city, is very open and includes several cultural aspects and provides an excellent location for the festival. It is home to several different types of artists. From the beginning, the city bet on the comics' festival and now comics fill the city. The success of the comics festival is due to its size and high quality. Writing and drawing comics tends to be a solitary activity and the Avilés festival enables interactions with readers, a development of a comics network. It attracts comics authors from various countries.

The festival started in 1996 as an initiative of the festival's current director, Jorge Iván Argiz, in collaboration with others interested in the comics world, who, in 1995, presented the project to the City Council of Avilés. The project was approved and the festival has been held annually in mid-September over a period of five days (Journeys). The organizers want to increase awareness of comics all year round, not just during the festival.

The aim of this festival is to offer a panoramic view of the comics world and its evolution; each edition emphasizes a specific topic (e.g. historical comics, Japanese manga, etc.). One of its most interesting aspects is the interaction that takes place between comics authors and the public - in bars, parks, and other public places in this small city. These face to face contacts are valued by the participating authors.

The organizers do not have an explicit strategy to link the festival with other local activities. In some years, there has been a carnival related to the comics' festival, and in the latest editions, the festival's promoters organized an initiative called "comics at school" which involved twice-yearly visits to schools by some Spanish comics authors to interact with students. In August 2018, it was decided to make a permanent space for the comics' festival in an old, converted ceramics factory.

The popularity of comics is undeniable, and the comics sector is one of the most dynamic publishing industry sectors in terms of sales and volume of work produced (Salvador, Benghozi, 2021). This has resulted in multiple events organized around comics around the world, often aimed at promoting sales. However, the Aviles festival is not part of this commercial festival network; the organizers are keen to maintain it as an "interaction space" based on the idea of culture as a public good that is available to everyone.

The distinctive character of this festival is linked to the strength of the relationships between comics authors and their audiences, and the festival attendees are all fans of comics and this form of artistic expression. The 
festival attendees are part of the festival; there are few restrictions imposed on interactions between the public and the comics authors. The Avilés comics festival is conceived as comprising "journeys" taking in different places in this small city.

\section{Organization and management}

The Avilés International Comics Journeys are organized by the non-profit cultural association "Friends of the Comic Strip of Asturias". The association benefits from support from the Asturias city council. Up to 2014, the city council provided all the funding needed, since then it has received sponsorship from Asturiana de Zinc of up to $30 \%$ of the funding required to run the festival.

The festival's activities and exhibitions take place in various locations in the city including the cultural center, the Atrium Shopping Center, the municipal art center, the Palace of Valdecarzana, the Aviles City Council and a marquee. Each year, four or five exhibitions are held in the city's exhibition center. At the end of 2018, a permanent space for comics exhibitions was made available in a converted ceramics factory.

The organizers hold twice monthly meetings, exchange some 200 e-mails a month and engage in frequent telephone calls. Also, since the three promoters are friends, they meet frequently which provides additional occasions to discuss the festival. In the days immediately preceding the festival and throughout the festival, the promoters work full time for the event. The festival also recruits volunteers to help during the event but there is no organized form of recruitment; interested persons use face-to-face meetings, e-mails, and social networks to signal their availability and willingness. The festival does not have a website (because the organizers do not have enough time to maintain or improve it) but its Facebook page ${ }^{13}$ has more than 2,900 followers and is the main mechanism for disseminating festival news. The organizers advertise activities on this Facebook page and via Twitter, and on programs on the municipality's website (culture section), local radio, TV and press, comics magazines, and comics shops in the city. ICTs are used regularly by both comics authors and potential festival participants. The festival organizers offer opportunities for interaction via e-mail, blogs, forums, social networks, and SMS.

The organizers are motivated by the love of comics and their keenness to cultivate interactions between comics authors and the public. This is why this festival described in terms of "journeys". This is interesting and emblematic of the local dynamics at work. The term "Salon" refers to a static situation where the festival is confined to an autonomous space to which visitors go. The term journey implies that festival visitors follow a path around the entire area of the festival. The organizers are keen also to keep the festival focused on its mission - avoiding a huge commercial approach - and involving "journeys" to enable meetings between comics creators and comics lovers. 
Table 9.3 The Avilés international comics journeys

\begin{tabular}{ll}
\hline Focus & $\begin{array}{l}\text { The aim of this festival is to offer a panoramic view of the } \\
\text { comics' world and its evolution, and to focus on a different topic } \\
\text { every year }\end{array}$ \\
\hline Organization & $\begin{array}{l}\text { The non-profit cultural association "Friends of the Comic Strip of } \\
\text { Asturias" organizes the Avilés International Comics Journeys }\end{array}$ \\
Activities & $\begin{array}{l}\text { Several activities take place in various places throughout this } \\
\text { small Spanish city }\end{array}$ \\
Originalities & $\begin{array}{l}\text { Interactions take place between the authors and the public in } \\
\text { bars, parks, and other public places around the small city }\end{array}$ \\
Location & $\begin{array}{l}\text { Avilés is home to several different kinds of artists } \\
\text { Comics authors are usually solitary people and Aviles provides } \\
\text { them with a natural space for interaction with their readers }\end{array}$ \\
\hline
\end{tabular}

Source: Authors.

The three festival promoters are decisive to the success, growth, and survival of the festival. All have a deep knowledge of the world of comics which are their passion, and their enthusiasm is inexhaustible. The festival is distinguished by the possibilities it provides for interactions between comics authors and the public which is an attraction for comics authors to participate without any financial reward. Some of the world's best-known comics authors attend the annual Avilés festival. Among the 100 best-selling comics in the world, 23 are from Spanish authors who attend the Avilés' Festival. Finally, the continued support of the city council is important: its leaders and political parties with responsibility for culture have changed over the years but the festival has never lost municipal support. On the first day of the festival, there is a reception which all parties attend, and the final report of the festival is sent to city council members. Although there is no strategic cultural plan due to time constraints, the comics festival is aligned to the general view of the council that culture is for everyone. This strengthens the links between the festival and the city. So far, political changes have not had an effect; however, should this change, since the festival depends on the city council for most of its funding, this is a potential weakness. Table 9.3 summarizes the main characteristics of this festival.

\section{Discussion and concluding remarks}

The focus on the creation and organization of festivals in the development strategies of many cities offers a new vision of the creative city. Organization of festivals can be considered a regional development policy (Crossick, 2006; UNCTAD, 2010) which provides brand identity for the city hosting the event. Specific events such as festivals enable visibility which might otherwise be difficult. They can be seen as complementing the city's identity constructed over time through architecture (Jones and Svejenova, 2017). 
The annual designation of European Capital of Culture which was introduced by the European Union in 1985 gives prominence to the organization of cultural events to increase the city's visibility and attractiveness and achievement of a unique image. It provides an attractiveness linked to the temporary, unique, and media-related dimension of the events rather than a distinction based on cultural heritage. Cultural, social, and economic spillovers from these events increase the cities' reputation.

The peculiarities of individual festivals provide value for the city. This identity and place branding help to ensure the survival and economic success of small cities perhaps not rich in architecture, culture, tourist attractions or digital technologies. The organizers believed the Angouleme festival was the international reference for the comics sectors similar to Cannes, Berlin, and Venice for movies, and Salzburg for classic music. The Angers festival aims at fostering the comics' sector in Angers through attracting authors in this sector that otherwise would not come to this small city. As suggested in the introduction, we were interested in the dynamics at work in 'small' festivals such as the two we have studied, different from the strengths and success of big international festivals, in terms of conception, programming, and economic model.

Benghozi and Nénert (1995: 66) conducted a detailed analysis of the Cannes Film Festival and showed that a major success factor was the ability to simultaneously pursue economic/commercial and cultural/artistic objectives that might at first sight be seen as antagonistic. It is famed for the quality of the works shown and also has a central position among the professional film community and has become the decisive platform for film distribution.

Concern over providing public access to various artifacts combined with serving the interests of the community of professionals and economic partners is not specific only to the Cannes festival or other major festivals. It relates also to various exhibitions, festivals, fairs, and biennales, and influences the programming of their activities.

Many festivals are accompanied by parallel events which cater for different audiences, are based on specific development strategies and extend the festival environment. In the case of the two festivals analyzed, the focus is on the location - similar to the Cannes Film Festival - which is enriched by the festival which in turn is enhanced by the various exhibitions and conferences organized alongside them. The aim of both festivals is to promote a specific culture. Visitors include both local audiences and international participants. The authors' participation is usually not revealed until immediately before the festival in order to keep potential visitors in suspense.

Our analysis highlights the specificity of the small cities that host the events. They have adopted a culture valorization strategy and have become culture clusters which attract various types of artists. The period of the festival reaffirms the cities' cultural identity and enables conviviality and acts as a tourist attraction. The unique characteristics of the festivals studied (e.g. the link between wine and comics in the case of the Angers festival) are 
enhanced by the attention given by their organizing teams to the ambience and locations of the events. A welcoming environment is the goal of all local festivals, demonstrated by good customer service. Dantas and Colbert (2016: 81) suggest that this makes a difference for customers: "attention to the level of service is particularly important in the cultural events sector, where supply exceeds demand". The festival and the city hosting become a single entity: they identify with one another, and they share the same attractive influence. The link with schools and students is further evidence of this. The quality of the hospitality and the exchanges between participants, authors, and exhibitors in the cultural ecosystem are important. The absence of a commercial approach is also important. The persons involved in the event organization, including volunteers, are passionate about comics and keen to support this local event. The cities are involved in the festivals and host complementary activities such as exhibitions and concerts. This point is particularly important because it is through it that the paradox that we pointed out at the beginning of this chapter regarding the creation of event dynamics in the book publishing sector is finally resolved. In this case, the organization of the festival involves the whole city, including various volunteers and partnerships with other economic actors including those not involved in comics such as wine producers. This suggests some substitution or complementarity between the novelty of the event and its embeddedness in a traditional territory.

These festivals have been supported by the emergence of new ICTs which have increased their attractiveness and diffusion. These ICTs represent new resources and new development opportunities. The digital revolution and diffusion of ICTs have affected the whole business world and are leading to a new business landscape. Their impact is particularly noticeable in the cultural sector, which to an extent foreshadowed the transformations and disruptions currently affecting economies in terms of business models, configuration of offers, and consumer practices. Digital technologies are having a disruptive effect on traditional CCIs' models: the book publishing and music and cinema industries are among the most representative examples (Moreau, 2013; Salvador et al., 2019). Innovation processes and outcomes are being impacted by pervasive digitization, which is questioning traditional theories and innovation management processes, and leading to the idea of "digital entrepreneurship" which emphasizes the profound effects of digital technologies (Nambisan et al., 2017).

However, their effects on activities such as festivals are less well documented and appear more equivocal. It cannot be assumed that digital technologies have had a disruptive effect on small festivals linked to the local territory and the unique experience they assure visitors. Neither of these aspects can be substituted by digital tools. The festival setting, and their organization are characterized by temporality and a focus which involves well motivated workforce and intensive short-term collaborations and leadership by one or a few persons (Abfalter et al., 2012). 
So, how is the digital revolution influencing the organization and management of small festivals? According to our case studies and the data derived from the interviews, it seems that the new dynamics are adding to the success of these festivals and consolidating the image of the cities hosting these events. ICTs are complementing the physical proximity necessary for the organization and management of these events. We would like to highlight the following dimensions. The analysis shows first that the business models of these events (Rajaobelina et al., 2019) are supported by the experience economy (Pine, Gilmore, 1998). In the case of the Angers festival personal dedications from comics' authors ensure a memorable experience. The link to the experience economy allows the economic model of these small festivals to be part of a form of permanence and reinforcement, avoiding the Red Queen effect (Kauffman, 1995; Voelpel et al., 2005; Barnett, 2008; Benghozi, 2015) of continuous search for alternative models. These small-scale festivals have no need to try "to run faster". They need only to ensure a memorable experience. Commoditization of goods and services demands a business differentiation strategy (Pine, Gilmore, 1998). Consumers desire memorable experiences: "no two people can have the same experience, because each experience derives from the interaction between the staged event (like a theatrical play) and the individual's state of mind" (Pine, Gilmore, 1998: 99). Visitors who recall the festival as special will become regular participants: the interviews confirmed fidelity among visitors over the years. However, the Internet and ICTs could enable new genres of interactive experiences (Pine, Gilmore, 1998).

While digital technology has profoundly changed all CCIs, we currently do not observe disruption on the scale of their effect on the economy, and no huge reconfiguration of their offers. We found no evidence of attempts to switch to online or remote festivals. Some music and film festivals have tried to offer an online experience sometimes with limited availability as in the case of live screenings. Others are using digital technologies to duplicate performances originally conceived in festival venues to provide access for a wider audience. However, most digital innovations related to festivals have been incremental and focused on improving the administrative functions (administration, ticketing, etc.) and interactions among existing audiences, rather than on exploring alternative forms. Innovation and ICTs have a specific place in festival organizations. Visitors want the memorable and "specific" experience offered by these small festivals and this enables to argue about the empowerment of a proper economic model related to the festivals themselves. Innovation and ICTs are essential to social networks which are used to diffuse information about the festivals along with traditional channels like radio and local press which are still important in small cities. Standardization combined with creativity results in an original and personalized experience and interactions rather than innovative products or services.

Research on some major festivals - Avignon for theatre, Cannes and Venice for cinema, Salzburg for music (Frey, 1994) - shows that to ensure growth 
and sustainable development, attractiveness and reputation, these events also require a professional marketing structure where producers and diffusers meet for commercial purposes. On the contrary, even if on a smaller scale, the case studies analyzed have maintained their original mission.

The lack of changes to the festivals studied is interesting and could be explained by lack of means to ensure their growth and development and expand and include an online presence. However, it could be argued also that it is their successful event dynamics and territorial anchoring that ensure their sustainability and identity. These aspects are part of a particular dynamic that is different from the forces at work in big festivals where sustainability and success depend on programming and professional marketing activity (cf. Benghozi, Nénert, 1995).

In all the editions of the comics festivals in Angers and Avilés, the aim has been to ensure a cultural focus. This is accomplished through the participation of both local and international authors, parallel exhibitions, visits to schools, and partnerships with institutional and business actors. The survival, affirmation, and originality of these small events may be linked mostly to respect for and maintenance of their nature and mission. The stability of these events is ensured by coherence and a friendly atmosphere.

\section{Acknowledgments}

The authors thank the organizers of the Angers Comics Festival (France) and the Avilés Comics Festival (Spain) for agreeing to interviews. A preliminary version of this article was presented at the 15th International Conference on Arts and Cultural Management (AIMAC), held in Ca' Foscari University of Venice, Italy, June 23-26, 2019. The authors thank two anonymous reviewers for constructive comments.

\section{Notes}

1 Author translation: "l'étude des manifestations temporaires telles que Festivals, marchés, foires et autres événements éphémères reste finalement relativement limitée".

2 http://angersbd.fr/

3 https://www.avilescomarca.info/agenda/jornadas-del-comic-aviles/

4 For a review of the literature, see Vecco and Srakar (2017).

5 Due to the pandemic and the health directives in force, the board of directors of the Angers BD association decided to cancel the 2020 edition of the comics festival initially scheduled for December 5 and 6 . The next edition is scheduled for December 4 and 5, 2021.

6 Vini Bandes Dessinées premiere cuvée: Vini Comics first vintage.

7 "12ème Angers BD : un Festival grand cru", by Yannick Sourisseau, Angers, $06 / 12 / 2010$.

8 Nonetheless, the association between wine and comics attracted contradictory reactions from the public: some liked it, others judged the link between alcoholic drinks and books often enjoyed by very young readers, inappropriate. 
9 Author translation: "Vin et bande dessinée sont synonymes de bon gout et de joie de vivre : il est bien logique qu'ils s'unissent".

10 Medieval times in 2004; nature and environment in 2006; comics and cinema in 2007; comics and rock in 2016; and so on.

11 "Le Château sort de sa bulle, dernier week-end pour profiter de l'expo", Angers Mag Info - Angers, 03/01/2014.

12 Author translation: "L'autre point fort c'est la façon dont les organisateurs " cocoonent " les auteurs. Pas de tapis rouge, mais une ambiance détendue où chacun prend plaisir, à échanger sur les projets de uns et des autres", "Festival BD d'Angers : toujours très convivial", by Yannick Sourisseau, Angers, 07/12/2009.

13 https://www.facebook.com/Jornadas-del-C\%C3\%B3mic-de-Avil\% C3\%A9s-195832180457638/

\section{References}

Abfalter, D., Stadler, R., Muller, J. (2012), “The organization of knowledge sharing at the Colorado music festival", International Journal of Arts Management, vol. 14, n. 3, pp. 4-15.

Baez-Montenegro, A., Devesa-Fernandez, M. (2017), "Motivation, satisfaction and loyalty in the case of a film festival: Differences between local and non-local participants", Journal of Cultural Economics, vol. 41, pp. 173-195.

Barnett, W.P. (2008), The Red Queen among organization: How competitiveness evolves. Princeton, NJ: Princeton University Press.

Benghozi, P.-J. (2015), "Culture and the red queen", Tafter Journal, $\mathrm{n}^{\circ} 84$ (September/October).

Benghozi, P.-J., Nénert, C. (1995), “Création de valeur artistique ou économique: du Festival International du film de Cannes au marché du film”, Recherche et Applications en Marketing, vol. X, n. 4, pp. 65-76.

Benghozi, P.-J., Salvador, E. (2015), “Technological competition: A path towards commoditization or differentiation? Some evidence from a comparison of e-book readers", Systèmes d'Information et Management (SIM), vol. 20, n. 3, pp. 97-135.

Benghozi, P.-J., Salvador, E. (2016), "Investment strategies in the value chain of the book publishing sector: How and where the R\&D someway matter in creative industries?", Technology Analysis \& Strategic Management, vol. 28, n. 5, pp. 568-582.

Benghozi, P.-J., Salvador, E., Simon, J.-P. (2018), “The race for innovation in the media and content industries: Legacy players and newcomers. Lessons from the music and newspaper industries", in P. Bouquillion and F. Moreau (eds.), Digital platforms and cultural industries. ICCA-Cultural industries, artistic creation, digital technology, vol. 6, pp. 21-40, Peter Lang editions.

Blichfeldt, B. S., Halkier, H. (2014), "Mussels, tourism and community development: A case study of place branding through food festivals in $\mathrm{Ru}$ ral North Jutland, Denmark", European Planning Studies, vol. 22, n. 8, pp. 1587-1603.

Caves, R. 2000. Creative industries: Contracts between art and commerce. Cambridge, MA: Harvard University Press. 
Crossick, G. (2006), Knowledge transfer without widgets: The challenge of the creative economy. London: Goldsmiths, University of London, A lecture to the Royal Society of Arts in Leeds on 31 May 2006.

Dantas, D. C., Colbert, F. (2016), "Festival de Lanaudière : Differentiation in customer experience ", International Journal of Arts Management, vol. 18, n. 3, pp. $79-85$.

Del Barrio, M. J., Devesa, M., Herrero, L. C. (2012), "Evaluating intangible cultural heritage: The case of cultural Festivals", City, Culture and Society, vol. 3, pp. 235-244.

Frey, B. (1986), “The Salzburg festival: An economic point of view”, Journal of Cultural Economics, vol. 10, pp. 27-44.

Frey, B. (1994), "The economics of music festivals", Journal of Cultural Economics, vol. 18, pp. 29-39.

Jones, C., Svejenova, S. (2017), “The architecture of city identities: A multimodal study of Barcelona and Boston", in M. A. Höllerer, T. Daudigeos, D. Jancsary (eds.) Multimodality, meaning, and institutions (Research in the Sociology of Organizations, Volume 54B) Emerald Publishing Limited, pp. 203-234.

Kauffman, S. A. (1995) "Technology and evolution: Escaping the Red Queen Effect”, McKinsey Quarterly, vol. 1, pp. 118-129.

Luonila, M., Johansson, T. (2016), "Reasons for networking in institutionalized music productions: Case studies of an opera house and a music festival ", International Journal of Arts Management, vol. 18, n. 3, pp. 50-66.

Mayfield, M., Mayfield, J., Genestre, A. D. (2001), "Strategic insights from the international comic book industry: A comparison of France, Italy, Japan, Mexico and the USA", American Business Review, June, pp. 82-92.

Moeran, B., Strandgaard Pedersen, J. (2011), eds., Negotiating values in the creative industries. Fairs, festivals and competitive events . Cambridge: Cambridge University Press.

Moreau, F. (2013), “The disruptive nature of digitization: The case of the recorded music industry", The International Journal of Arts Management, vol. 15, n. 2, pp. 18-31.

Nambisan, S., Lyytinen, K., Majchrzak, A., Song, M. 2017. Digital innovation management: Reinventing innovation management research in a digital world. Mis Quarterly, vol. 41, n. 1, pp. 223-238.

Pine, B. J., Gilmore, J. H. (1998), "Welcome to the experience economy", Harvard Business Review, July-August, pp. 97-105.

Rajaobelina, L., Dusseault, P., Ricard, L. (2019), "The mediating role of place attachment in experience and word of mouth: The case of music and film festivals", International Journal of Arts Management, vol. 21, n. 2, pp. 43-54.

Salvador, E., Benghozi, P.-J. (2021), "The digital strategies of publishing houses: a matter of book content?", International Journal of Arts Management, vol. 23, n. 2, pp. 56-74, Winter.

Salvador, E., Simon, J.-P, Benghozi, P.-J. (2019), "Facing disruption: The cinema value chain in the digital age", International Journal of Arts Management, vol. 22, n. 1, pp. 25-40.

Snowball, J. D. (2013), “Are arts events a good way of augmenting the economic impact of sport? The case of the 2010 FIFA World Cup and the national arts festival in South Africa", International Journal of Arts Management, vol. 16, n. 1, pp. 49-61. 
Suomi, K., Luonila, M., Tähtinen, J. (2020), “Ironic festival brand co-creation”, Journal of Business Research, vol. 106, pp. 211-220.

UNCTAD (2010), Creative Economy Report 2010. Creative economy: A feasible development option.

Vecco, M., Srakar, A. (2017), "Blue notes: Slovenian jazz festivals and their contribution to the economic resilience of the host cities", European Planning Studies, vol. 25, n. 1, pp. 107-126.

Vestrum, I. (2014), “The embedding process of community ventures: Creating a music festival in a rural community", Entrepreneurship o Regional Development, vol. 26, n. 7-8, pp. 619-644.

Voelpel, S., Leibold, M. Tekie, E., Von Krogh, G. (2005), "Escaping the red queen effect in competitive strategy: Sense-testing business models", European Management Journal, vol. 23, n. 1, pp. 37-49.

Wong, J., Wu, H.-C., Cheng, C.-C. (2015), “An empirical analysis of synthesizing the effects of festival quality, emotion, festival image and festival satisfaction on festival loyalty: A case study of Macau food festival”, International Journal of Tourism Research, vol. 17, pp. 521-536. 